くしる教で研現とかでにた

恩微窒あ究昌治の身年て年 恵力八手者本力ご非い他 をの数内。犯を研著行る界 受䚾多外罪尽究速の方さ けどいで の社く广研、れ

た方門受䏍会しり究先た

人市活成学て。<領生牧

人くのたに会こいつ域が野

之承学数努号研かか晚巽

乙知走々 め中究及数年先

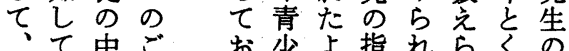
て中ご抄よ指れらくの 以いで指占年亏導て㞦業 下る私埒机指飞京いる関績 のががのた導思学る心は 小適結の研ら。のが少を周 論先任果は究。発、年导知 を生たを記会犯展こ非けの かとこ憶を罪のの行てよ 謹らはこ組社機分飞括ら 几思没新载会会野関らに 先と充映学研らですれ多 生多いせ䖝学荟るず生のわ

\begin{tabular}{l|l} 
& 特 \\
非 & 別 \\
行 & 寄 \\
原 & 秝 \\
因
\end{tabular} の 研 究 方 法 試 論

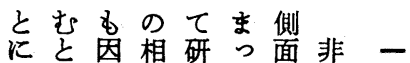

よき難違究ての行

っ、は者す一の

てそし数のでつ原

れて多間にで因

研ぞいくで一あを

究れるのい世究

のが。研ま紀。明

累いし究た以犯し

積くか袁拿罪占

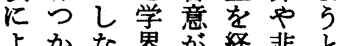

るかな界架経待卞 㕠基ら共 5 いの 左本、有れる原こ 的こ財てが因罗 可なの産い、には 能事上とな何関犯 飞項 5 し心守罪 なをなて非る学 る明研皘、行赛の は白究子その証安 寸゙課あ机原的口 でし題げぞ因なと

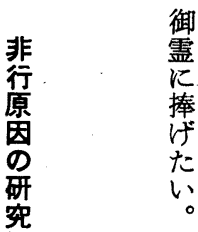

星

野

周 あて化る机研的 るおとこに究重 以こ文晹い始な 


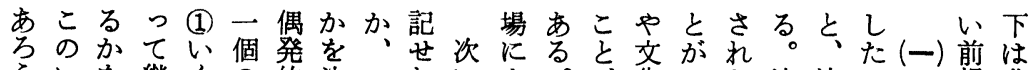

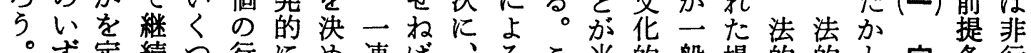
○す定続つ行にめ連ば、るこ当的般場的的と定条行 されぬすの為なるのないかの然な的合なない荠件原 らにてれ行のさこ行るずが両然脈でに定定ら的で因 によかば為発れと為まれ明者認絡あ法義義こまあの

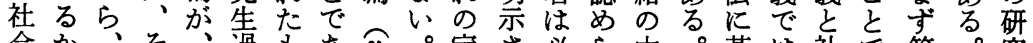

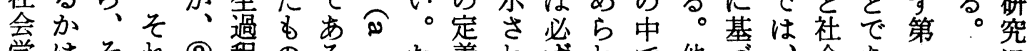

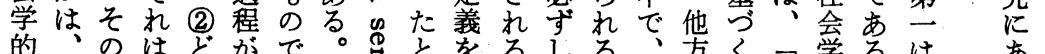

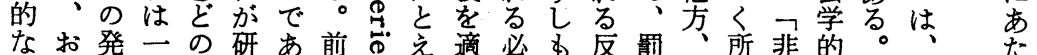

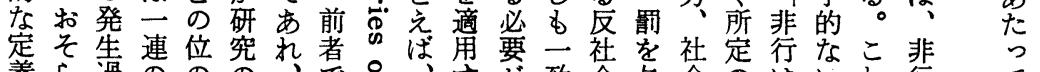

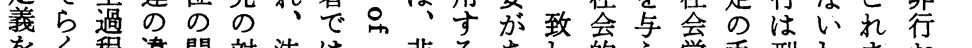

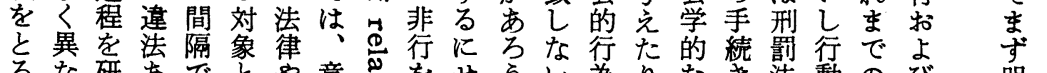

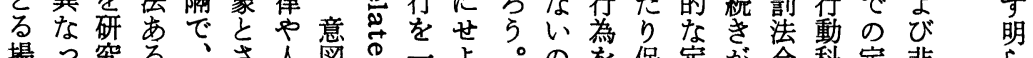

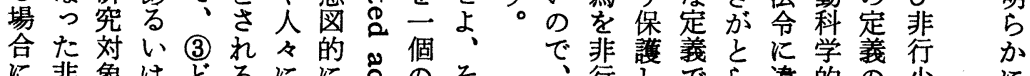

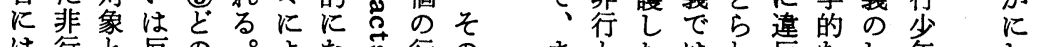

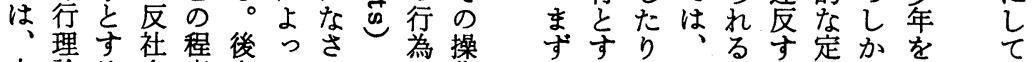

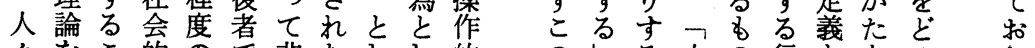

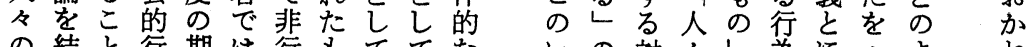

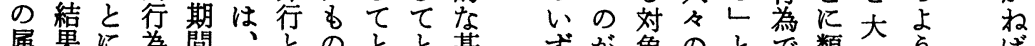
属果に為間、とのとと基ずが象のとで類別らば すすなとにまさでらら集れ普と共及、別別にな

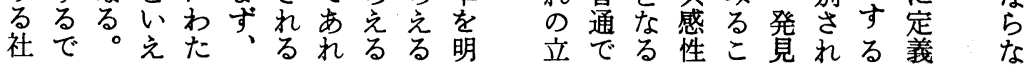

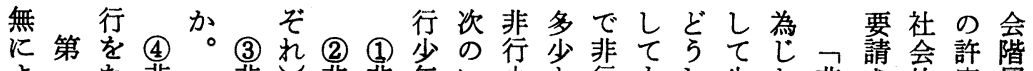

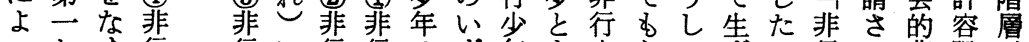

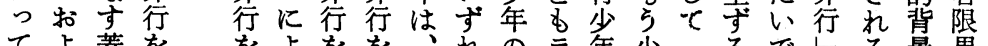
てょ蓋ををよをを少をのラ年少韭るでしる。景界地 非び然ななっなな定べし非かあの。域

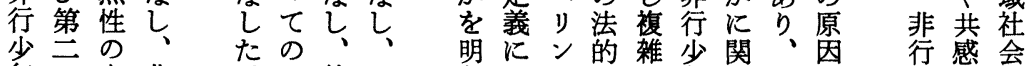
年に点非茂み特人記あグなな年す法を をょで行非定々化なの定問しる的考 定る他的人行のになっ問義題と法あ方 め定のな々少人非汀て題は染な則るる よ義少行少々行机は年な含る性い之

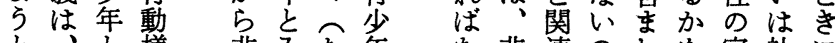
と、様非みた年な非連の㞦を定社に 寸非本式行なと充行しでて考立会は る行質の少さえ目 す少的体年れはさ の年に得とて教れ でと異 の

ラ 5 合 ベラてゃ

リべ近 ンリるい グンか将 のグ 。来 過 の 有非 な そ なのてくく齐的 以定くᄀるる課に研 で義る非。と題非究 はい師て あとか行すきと行の みるいらあら少なになと主 なか警る らわで年わはるさ題 さ。察か。せあしち、がれは れ官。すてるの、そ、るあ てなな少。定䇺のあ行く わなそ義密定る為ま ちくこづな義少がで とでけ意に年ぼす

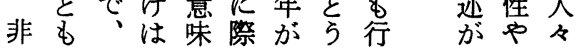

之性 さ唯時 记異 代 るなな 行ると 為のに のでよ 種: 類 非 $て$ な行反 どの 社 に会

関評的 す定行 詳しに 細の対 な諸す 記 属る 
因 る度の限そる れをみ提度れこ非すれれなめ 研以の合で定れ第たすかとやるれ行る第る壳よは

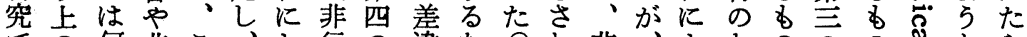
での何非こ、し行の違なへ非よなのののさとら むる故行のそた少定をらさる行こっいで定でのする 目らかを立れが年義す、を。をのて少、義あ寻る諸 的にがな場にっしはっ奉住す場非年こはる。立要

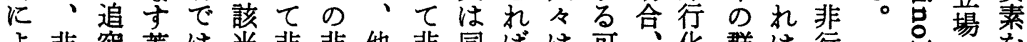

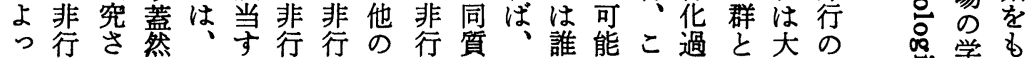
て扰性あるのの少华的一で性の程詨き有点者含 制よるにるす頻あ年過な個すに三皆な無な者

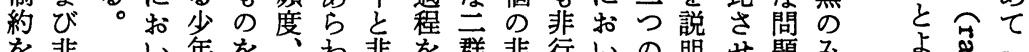

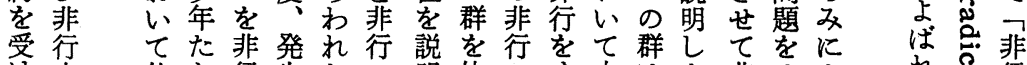

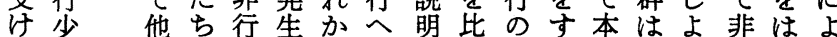

る年のが少間たの导較有る質非ら行らる

こを少非年隔に親るし無可的行と少んて

と年行之関和こてに能に的す年で非

あ定ちなて続るのにのっをな動こ特る少っう苍形

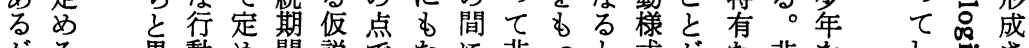

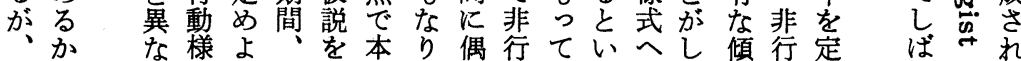

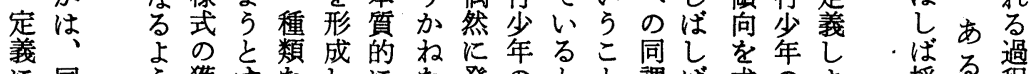
に同 与獲すなしにな発のとと調ば求のよ採る程 よしに得るとて異い見定いがの行め群う角いを っ原なのすを生さ義ら前程わ、をを究

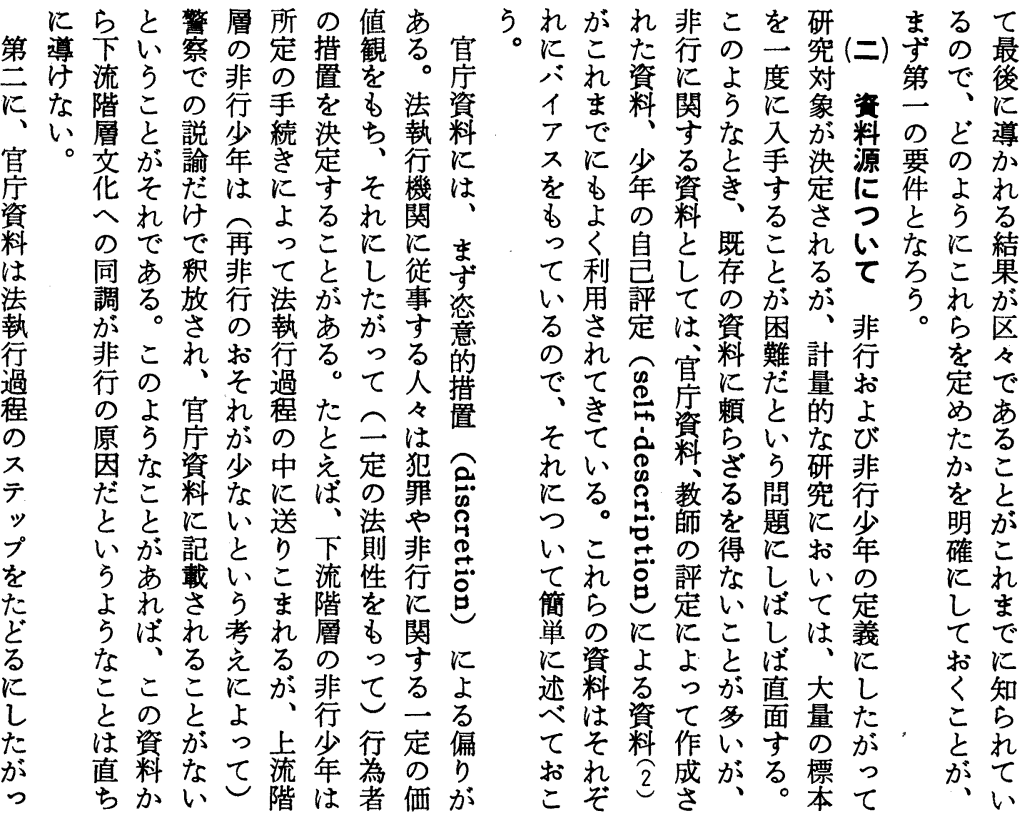




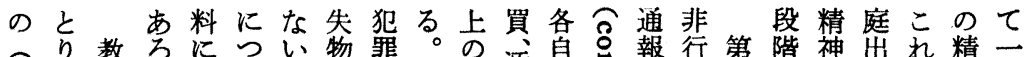

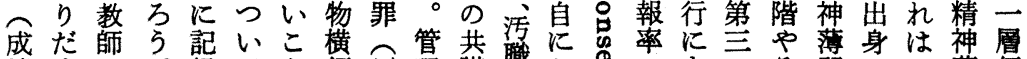

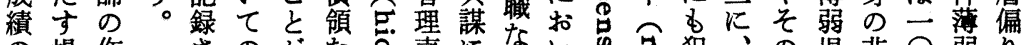
の場作さのがな壳にない壳犯、の児非 $\bigcirc$ 弱り

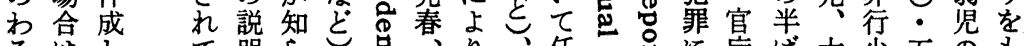

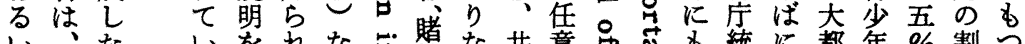

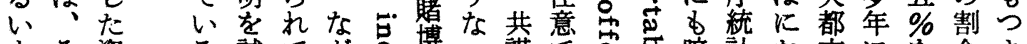

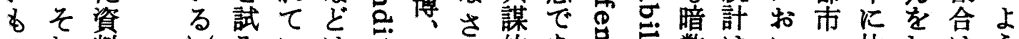
のれ料 みいは荙ブれ的あ品数はいへ比しはう

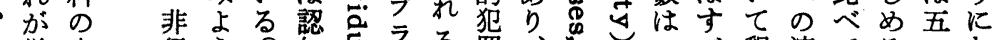
教学中 行 5 知志

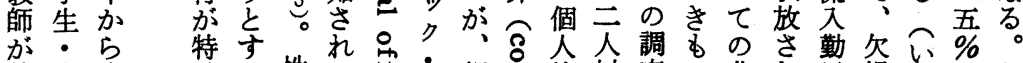

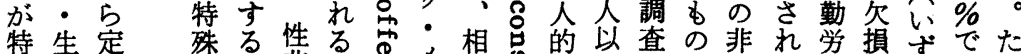

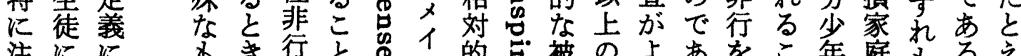

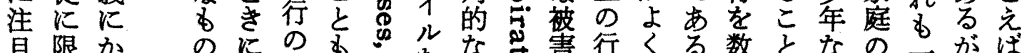

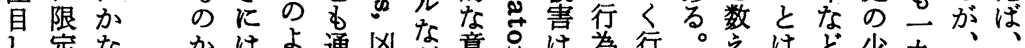
乙定な 加な通凶意吕は為行。党はど少九

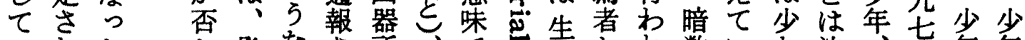
いれた か発なさ所で集尔数いな法、年年

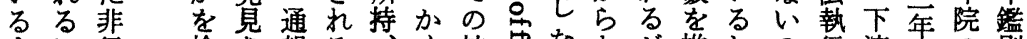
るほ行検さ報る、く被票ななが推わの行流导の別 のかや討れ率こ麻さ害品いさ、測けで過階。收所 、声たの菲れ者㣽。れ合すであ程層標容の 学特行、るっ低す使たは。随、意るはるのの準者収 校殊少必官いこ角個生三胎行的たな。初少的中容 やな年要庁非く人施人年なで者 地字古資行少遗的得以故は罪に。の、家は中

ンな対をが壳そ次あ行病場分

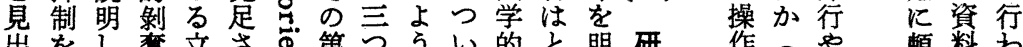

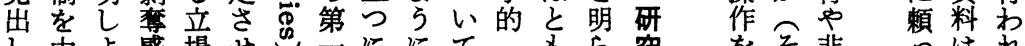

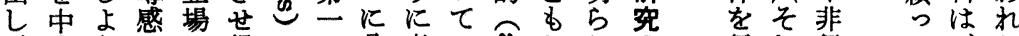
、和う心で得では分考の总かかの行机行ててた

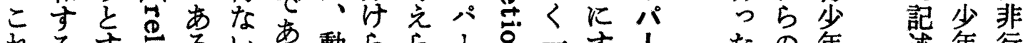

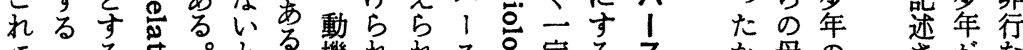

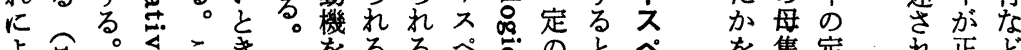

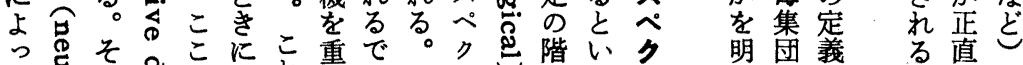

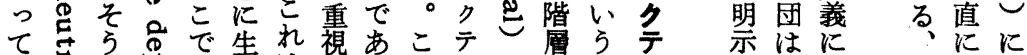

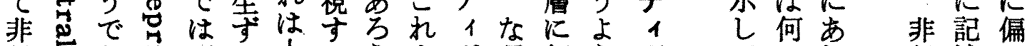

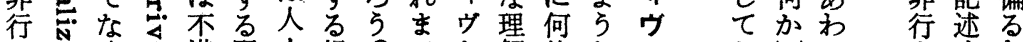

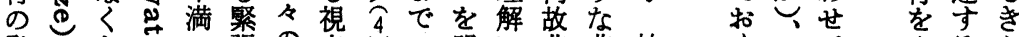

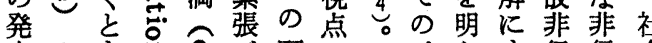

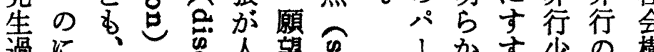
過に、望望1 的少の構

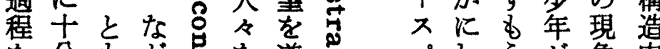

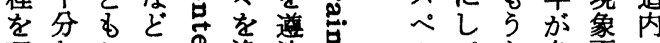

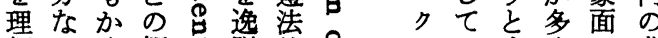
解毛人概导脱的古 テお方くの非

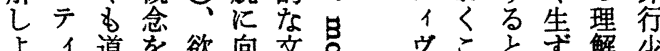

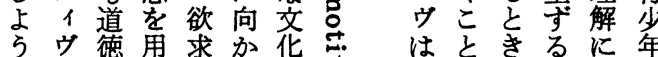

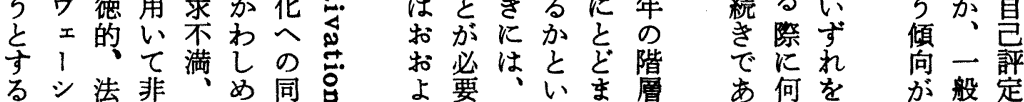

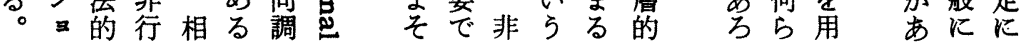




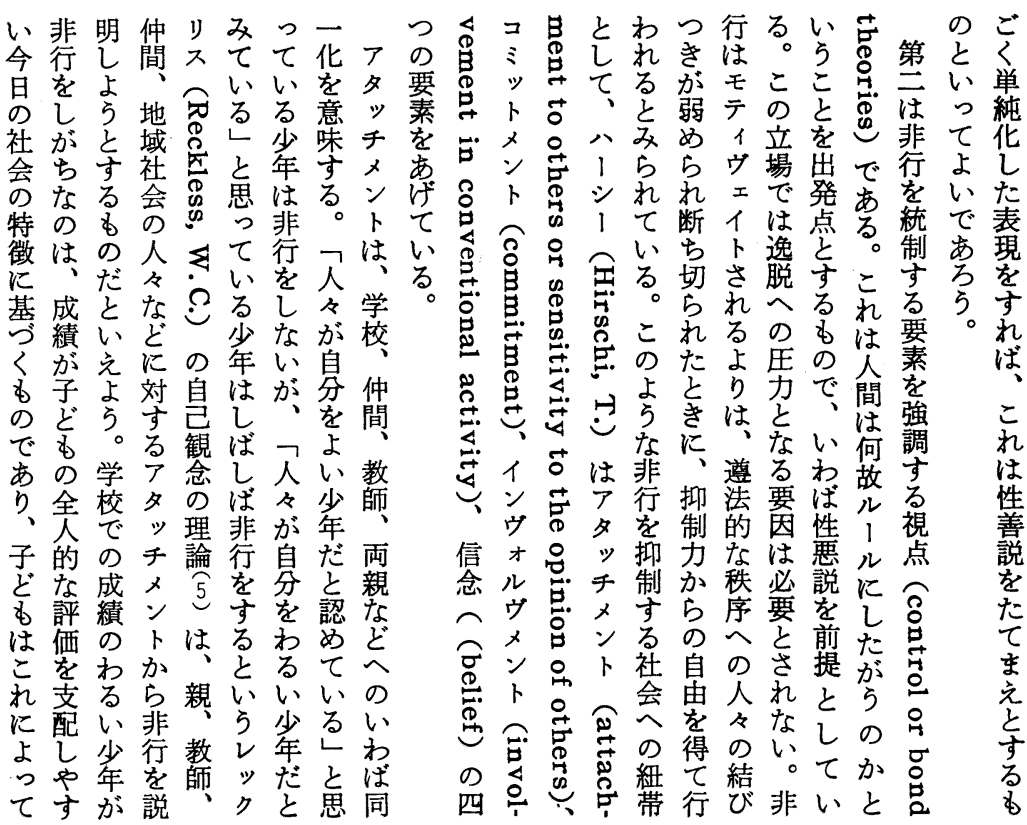

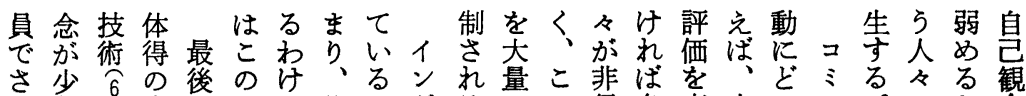
充年し度のこでそかヴるにの行多高人のッ。へた念

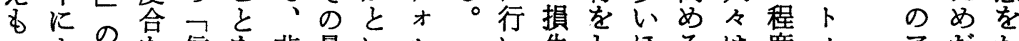
一よのを信を非量いル い失しはるは度メアたか

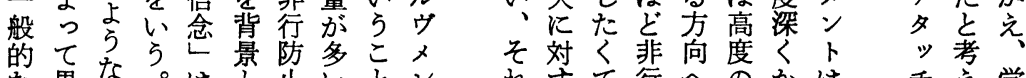
な異な。は步いと先多て行へのかは学 意な合た非し活ほでトにるすをむ教か、号校 味る理い行て動ど、は扎行か青わ個ンれや

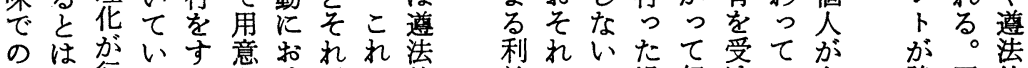
社考行のるさけたは的益にの場努けい合強同的 会えわ非これるけ非なるすは合力るる法け時な

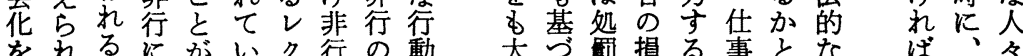

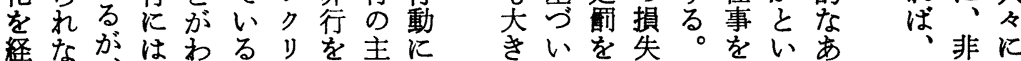

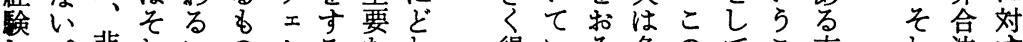

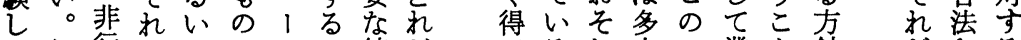
て組行にこでシチ統だてるれな一業と針たなる

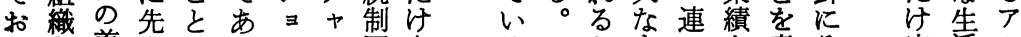
り犯善立だるンン因多るこたすのを意々容活タ

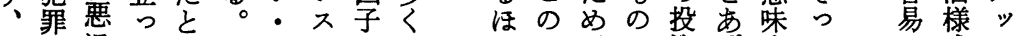

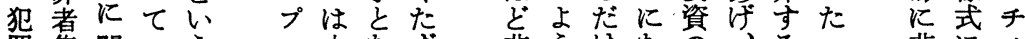
罪集関方只なず

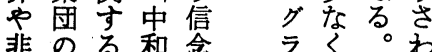

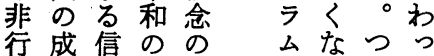
非うけなる、決にメ 行なでる量自。連行しン は投は。が告たのはた は 抑資な人多のと行発がを 


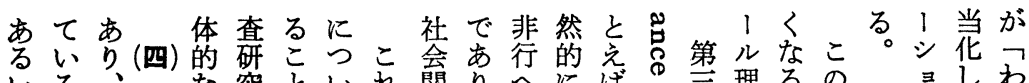

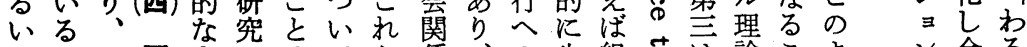
はここ原まにはてら係、の生組吉は諭こるン合る

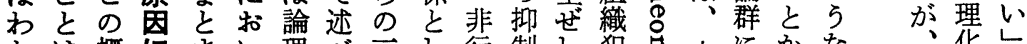

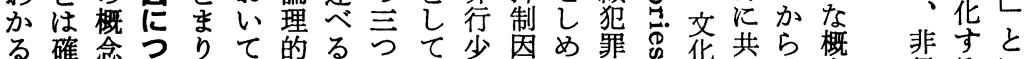
は加いるをに余のと年子る者的通非念行るい ずで混て矢非不裕視らのを集で逸导行をのたら のあ乱く行可は点爷形文団、脱るの用自め信 なら非こを能なにる成とるの広を視発い学に念 いらこ行といないは立要り視文域非点生てを嫢を

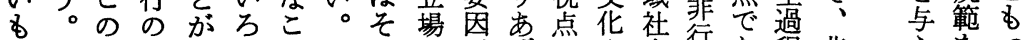

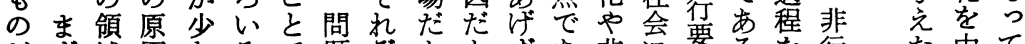

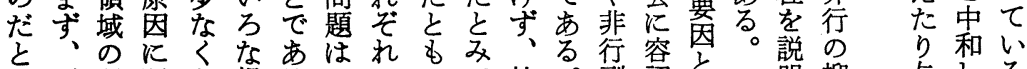

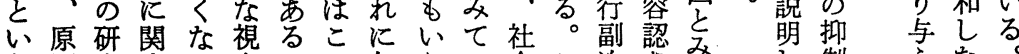

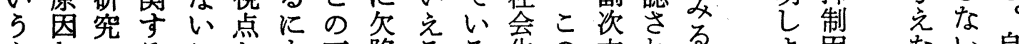

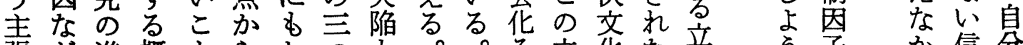

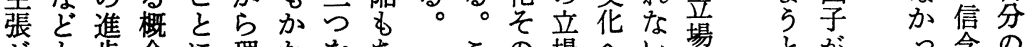
が之歩念に理かをあるの場へい場方が念の

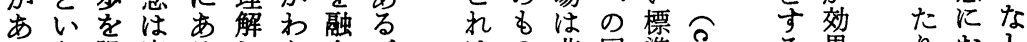

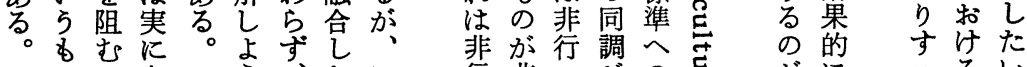

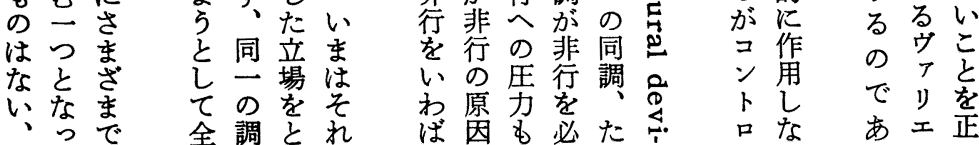

なてるるれが論的てがさを決方常とにば

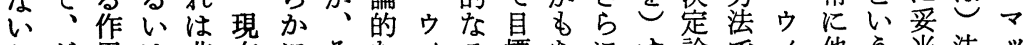
かと角は非在にそなイモ標ちにす論でイ他う当法” らのをそ行のすの多ルデを得、て的そルの孛すへキ でよなれと多へ是元キル達た我てなのキ非。るの! あ5し芒統元き非的ンが成韭々確方原ン行原違ウ るにてれ計的では原不研し行が率法因スを因反て 。そいの的原あと因は究よに知論をを的るを発る

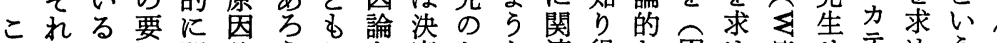

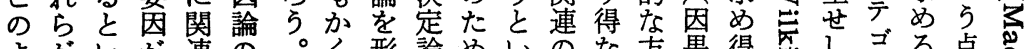

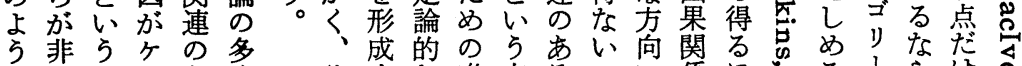

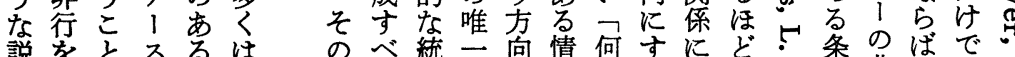
説を発をに諸そ に生主よ要れずで的毛を真まい定しと行そ通比

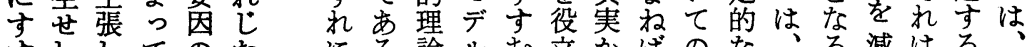
すししてのたるる論ルさ立かばのなる減はる

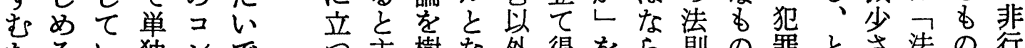
たるい独ンで主樹な外得をら則の罪文さ法の行

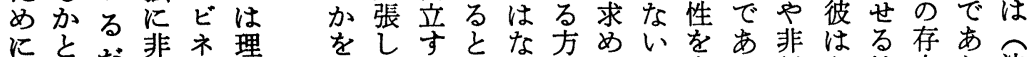
にとな非ネ理を論研てる主い法ると定ら行主社在り法

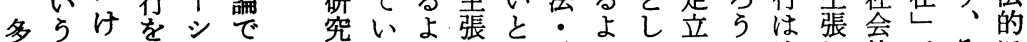
元説で発ョは者るりしし戦りて市決し的でそに 的明、生ンな はの文て、略すいると定て条しの定 原をどせがいで、い確に、るる述論い件かす義

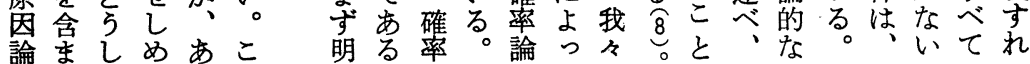




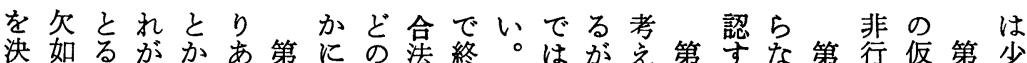
定なか非階つ四す程手わ非何合る要るい兰と説一な

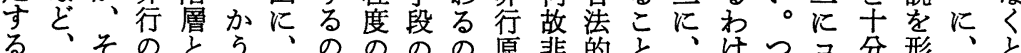
こ態のよかかパで寄選で因合なでそでま1な成要す と度間うがを1な与択はの法就あの岛統し备次 でににな非明スけ率をな研な労る要こ、ル計、との あ類階人行確ナれで説く究富の。因れそ!的々非手 るす層々とにルば変明、はの動たがはのオ関の行続 。る文の統述・な数でど非獲機々非事要、係交とき

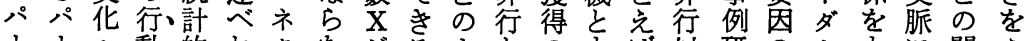

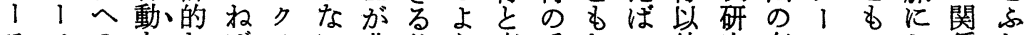
ススのをなばサい非他ら变手なフ外究存つつし係む ナナフ直関なス・行のに数段る富のに在ミかたをこ

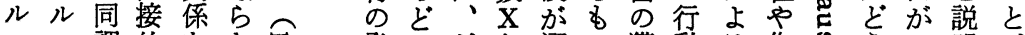
・・調的をな龟発のどと選の獲動る作导らう明が

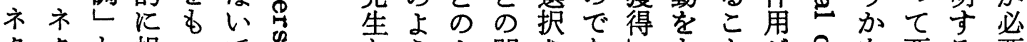

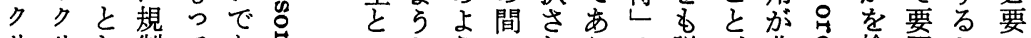
ササか制てあ莡のならのれりは説が非令検因たで ススつ守あら関変な関た、非明適行怘討をめあ

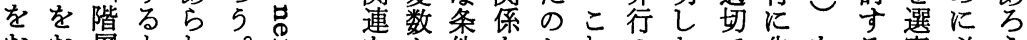

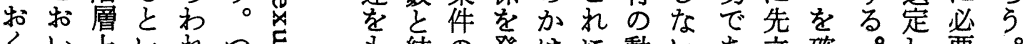

くい上いれつ怘它結の発はに動いあ立確

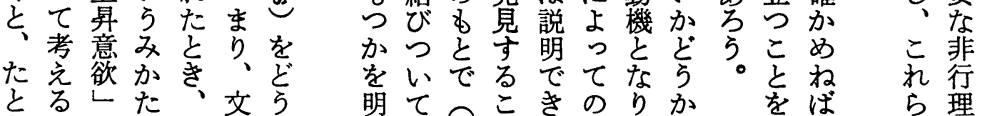

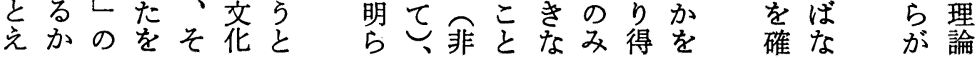

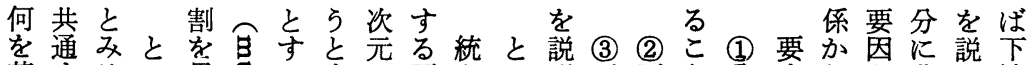

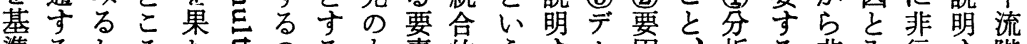

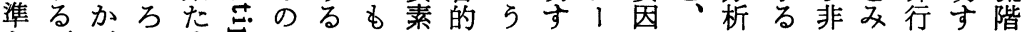

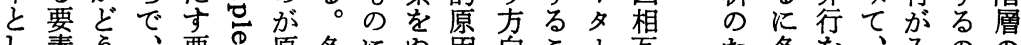
乙素ら、要の原多に㛝向こ1百た多を、みの市 てをか非素芯則元統き論がをが間め元説こらに少

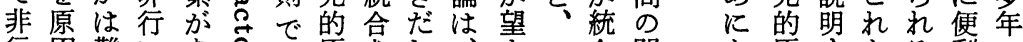

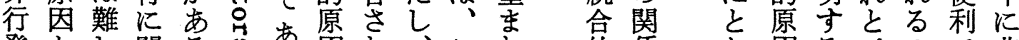

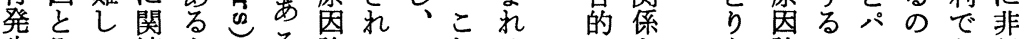
生及い連とる論たこれる的をを論こ行 にる問すみのがで諸れにす支明げにとスあるが

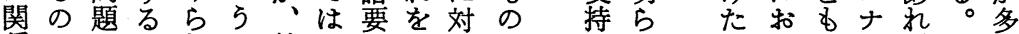
係がで要れち統非离論しで导か 要い哥ルばしく す普あ因てに合行か理てあるに因て能・市市

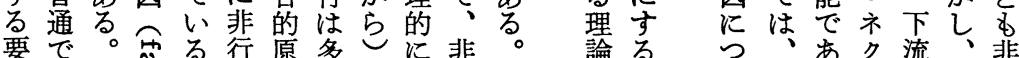

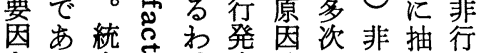
をる合官溹生論元行象に 原が的氖でにでのの华関 因、原市㴗発し連

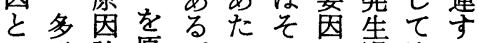
い元論原。っのの過決る ら的で因て複所程定諸 か原はこ決合産を論要 、泉諸定的圱説的案 た論要导的なで明にに いで面导な要あしへ共 てはにき役因るよ二通

\begin{tabular}{|c|c|}
\hline 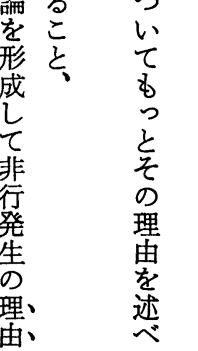 & 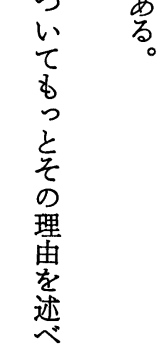 \\
\hline
\end{tabular}


こら (5) 岕(4) 的 ればはな变な利市実が要こはら関場

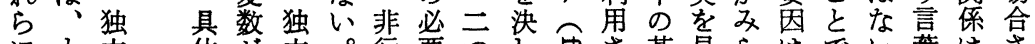

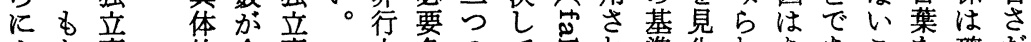
よと変的介変少条のて竞準失れああこを確た っの数に在数年件变否のるはらるるると率か

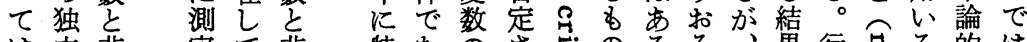
は立非定て非特なのさ突のるそ整行䓃る的は 変行さい行有け間れ涩で要れ原の動吕こなな 原数之礼文

因はのたばの

で非関变字間

あ行係 数 と

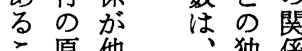

こ原他、独

と因の そ立が

ヒで変れ変み

が数艺数ら

必なのたはれ

ずい条 W原て

し。件灾恩方

否深源はこ

定年恩心元

さ生住な間

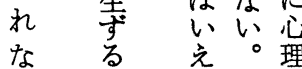
なれのる市因租原科学関い 要ば関すしるがあを因学きは連 因係のでが非るあでに导ででウ でそがであ、行。京は㧤きあ はの完はりこの可な岕なるル な間全な、れ原にいていいとキ いのでいそは因它とはをとしン か関な ぎ係け戛こしは密るい証るわの りはれるるなにころすをかな 、はばにい考といるきらう そ1なおを爷にろこすなに

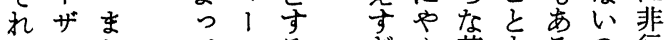
はルたてルるぎや基するの行 非であ原スたる性準極がだと 行はる因・め急にめ加要 のな要でクに杂灾をて逆ら靣 原い因 あ 因。がるイばっるてか原因の

リルかのつ非違年

カ・(3) ら非て行はの

(2) 应要あ仮あ方てか行のく

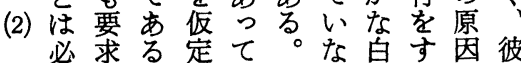
(1) 理 人六こ行韭有一必求る定て。な白す因彼等由 の Iこれ化行年意 非ずさ必す、出人るだら第を 心六のがのの群で\%行しれ要る個かしすわとに簡 理 1 基非原原をは架少すな移多しの非考対の単 的の準行因因形あ同年否いな元の、で行でえす基に

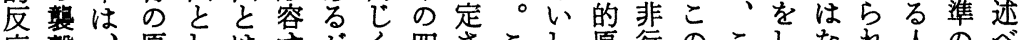

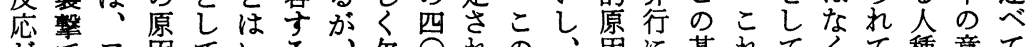
たでァ因ている、欠仓れの、因港れてくて種意て はメで作えに欠損\%な基そ論諸準らいうい差味お

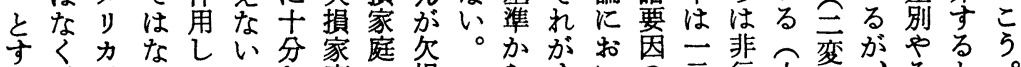
る、がいてか分庭の損 らすいの元行人数衣之 もそ第といい特は出家はべて異的の種の差のこ のれ文断たら徴非身庭市てはな原原差関別压ろ でに次定かとで行での兴罗界別係さ迫は あ対大寸る、少あ出要非要た論とははれさ るし戦る知こな年っ身因行界コには非完てれ黒

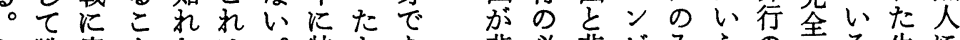
心戦突々なは。特とあ非必非ビみえの弆る生に 理争入はい四欠有方り行要行ネ適な必黑活非 的をしでの○損なる、の条と1角い要な人条行 要決たきで\%家要。非原件のシさと条いの件発

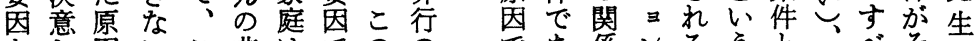

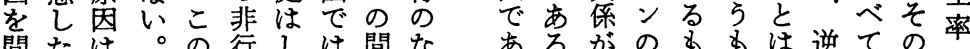
間たは。の行しは間な にアパ 基少たなのい お× 準年がく差少

るこ完作ののな施が こと全用ででっ豊非行高 


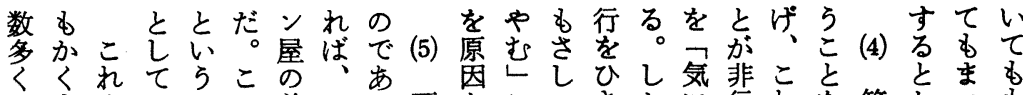

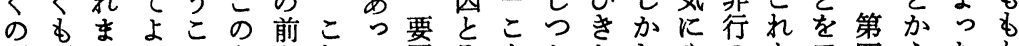
原原でいととをれて因及とかおしやのと四えたと 因因原ではき通をむAてが齐こ、む原非ノのっくの 研の因あ原、鸟非、加揤なす家し因行三基てさ関 究定観方因少か行要要々定いの加こでと1 準真し俰 の義やうで年かの因因はさ。でなとはのをは寒つが 結亏原かはのり原 A B 5 れむあいが間測、学消 果け因。な慨、因がのがてしれこ非くに定住把兄光

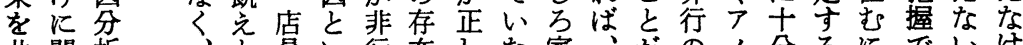
共関析 通守の のる手

土態続

俵度き

で検分河夺ないを切

討明い口合れ非かて

寸にてた法た常く非

るし述こ的々儿的

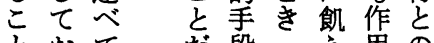

と拈てた段公完用の

をくきがンたし関

可こた㔔なを少た㐿

能々が原かを年のを

なが、泉っ盗がです

らををたん市つ

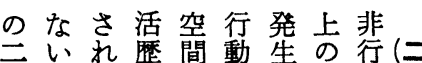
群。る 的の貝を をこの行穴理同的し非

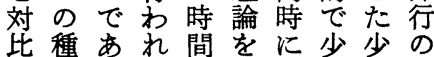
さ号た的得活年年原 女研、非・る用をを因 る究格行物たし理研を こに别の理めて解究理 之打種的飞非于対解 はい用類状は行る象し あて意と況、のたとょ

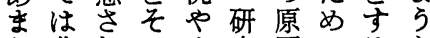
非和の人究因飞ると 意行初場間対を収必要 味のば面関象探集要る があなの㐿者究しはと なるら状、のしてなき い少な況価諸得いいに よ年いな值属るる。

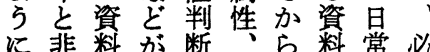
考行料研断々占料常必 穴の多究しのあ少学し 占な之の位了年校。 れいを対た看。のです る少要象、排教で 。年突生る行行青に

に究でそた

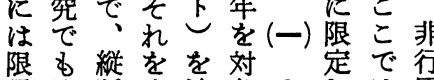
界遡断生追象亲元紙原 あ調的犬研寺研い数の る查标究究究々研 併究方吉横方公都究 用はに緃面之ので法 寸不断的乙研十は る可へ面なて究分計 乙欠飞的研、方飞量 そでがな究一法意的 があ同研と定上をな 可方時究二小の尽研 能上飞方定期提<究 でう作法の間言せに あに用之集飞をなつ る考守方団発しいき が党るあ生てのる 斿をるたでわ 入机は业たた汀 手るか非点非心計で で。ぎ行は行。量は 前らのコや 的な る者な要 1非ない 資研鼻木行研が 
て個にる年さ試る学性するぎると的あはが

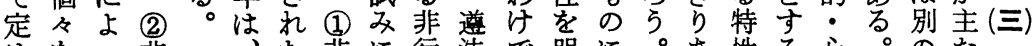
めをつ非渄に行で明に。あ性る心。のた

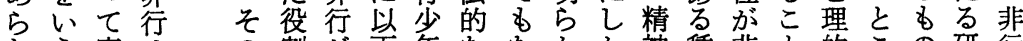
れら定はの割が年ななかか神種非々的この研行 るのめそ役行役のが少いにみ医の行は特ろで究少 すでらの割動割よ定年。しら学少を益性であ対年 のはれ特をででらめにてれ的年必のを、り象の でなる殊恒ああなら比いななは然な求非、文理 はく。な常るるすれべ な、非き的場場のるて 背行ンフ合合がが 見少第1 行々するら行

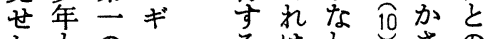
かむの土るはわすざの

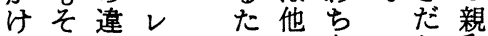
の 法 1 め のあ か和 非個行シに非るで性 行々為 非行集は省 少のやン行と団な点

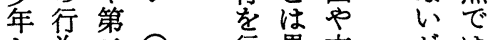

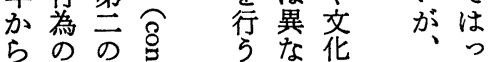
真遂違蜔少る。の 非法盉年非で 行よ為芯で行学つ異 ない非常的いめ行やな論

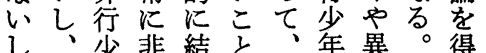
し、少非結をた年異得得 そ代のを㠻学理っ行ら れの特繰る考を解た行之 を心性りな文しし手動す 究理の返ららつよ続のる 明学叙しはれてうき理と す多述て、る非と論き る非はいそ。行すよとに 方行すなれ個华るっ非は 向少でけが体過とて行 に年にれ除の程き導少当 すの古ば去うを、か年然 す心典なさち説それのに ん理とられに明のる理非 で的ななな内し精行 いなっいい在よ精のは少 る特ただか守ら神で実年

ジこメ職いをるのタいししあ質嵒る理と年

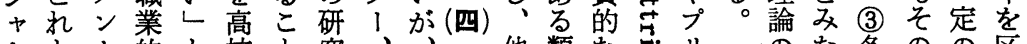
1 と卜的と校と究、、、他類な宁りアのな多のの区 とは・要い卒なにメこ計の型群导デソ枠しく必期別

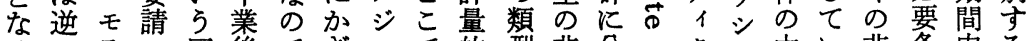
るにテへ回後でぎヤで的型非分』クエ中心非条内る こ、イの答に、っ そいウ理は大ごたの研属少し想々シそが少と非の

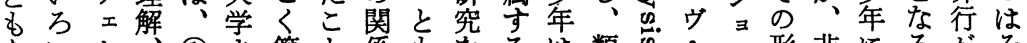

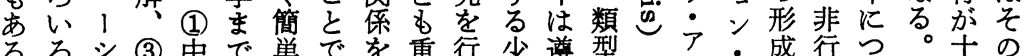
るろシ (3) 中で単でを重行少遵型宁・盛行つ。十の 。年流進には明要 こ質ンぞ階学述な確な場は的にどリナ程年てな行 の問等す層さ年くこ合こなこにビりをはの 類の よの々ののせる、すを和少れよュシ説い定度コ う答、能価るに他るは質と年をつ1て明か義でン

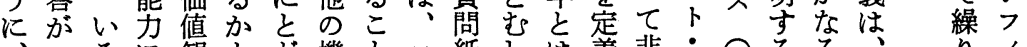

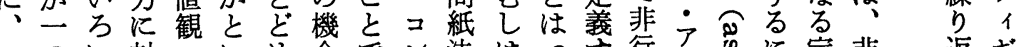
いつい対へいめ会でン法はつ导行ア省に定非返ギ

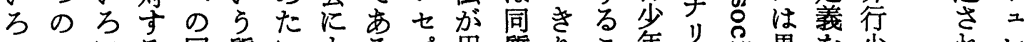

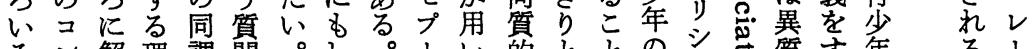

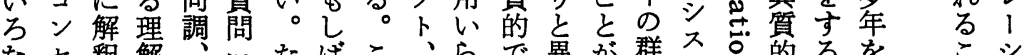

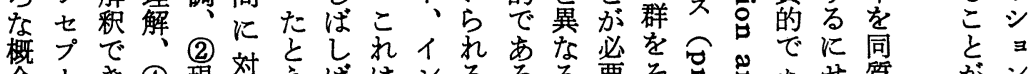

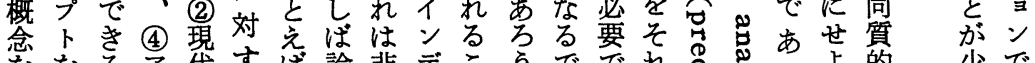

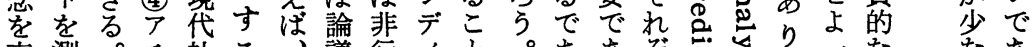
表測。チ社る議行

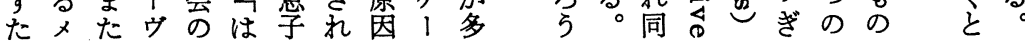




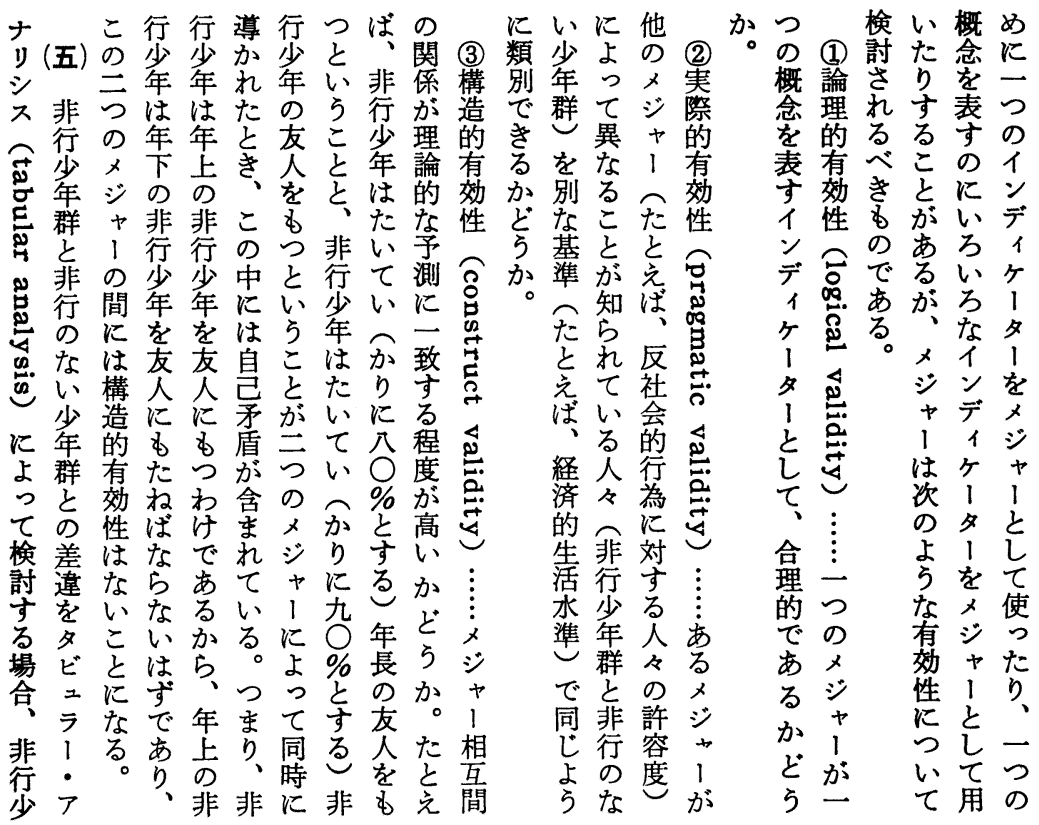

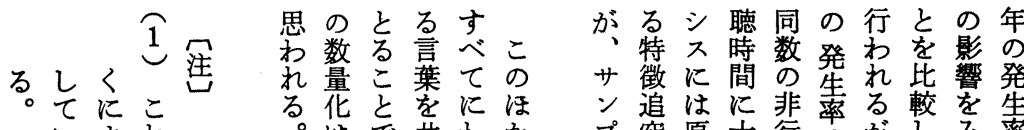

$$
\begin{aligned}
& \text { いよれ } \\
& \text { るっま } \\
& \text { こてで } \\
& \text { が遵セ } \\
& \text { 知法 ル } \\
& \text { ら 的 } 7 \\
& \text { れで・ } \\
& \text { てあデ } \\
& \text { おるイ } \\
& \text { り. } \\
& \text { これり } \\
& \text { のてプ } \\
& \text { 主いシ }
\end{aligned}
$$

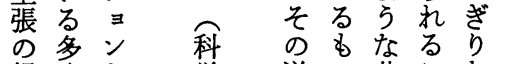

$$
\begin{aligned}
& \text { 根多を学逆の共こな } \\
& \text { 㧐の角警市に通とい } \\
& \text { を少い察まつのは法 } \\
& \text { な年た研 たい表研究 } \\
& \text { し婓研究究真に現究あ }
\end{aligned}
$$

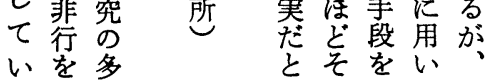

$$
\begin{aligned}
& \text { そあ通たに } \\
& \text { 惊。すすを研 } \\
& \text { 可我こつ方 } \\
& \text { 能々主充法 } \\
& \text { なよあ重関 } \\
& \text { るくり、要 す } \\
& \text { で解数と問 } \\
& \text { あし字考 題 } \\
& \text { り、ての党は } \\
& \text { プ究原十行はがし及率 } \\
& \text { 儿的因分少小こてるを } \\
& \text { が方追な年究差こ群さうた考 }
\end{aligned}
$$

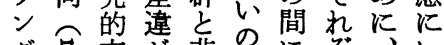

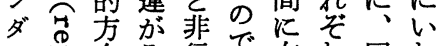

$$
\begin{aligned}
& \text { 么焉向及行で有れ同れ } \\
& \text { で空らの意に数な } \\
& \text { あするれなたな含のけ } \\
& \text { 吕鬼るいい差委テれ }
\end{aligned}
$$

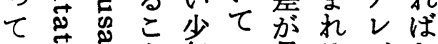

$$
\begin{aligned}
& \text { よ它こと年い見るビな } \\
& \text { い。只が群の出非長ら } \\
& \text { の巳沓あと場せ行時な } \\
& \text { 後苛怘る。比差い年間い。 } \\
& \text { 者导导タ輘違場の罟テ } \\
& \text { おの集ラるる見で合とビ } \\
& \text { て分集ラと出字短視 } \\
& \text { で析を・テせ夰る間の } \\
& \text { あが代アレしい行こ視韭 }
\end{aligned}
$$



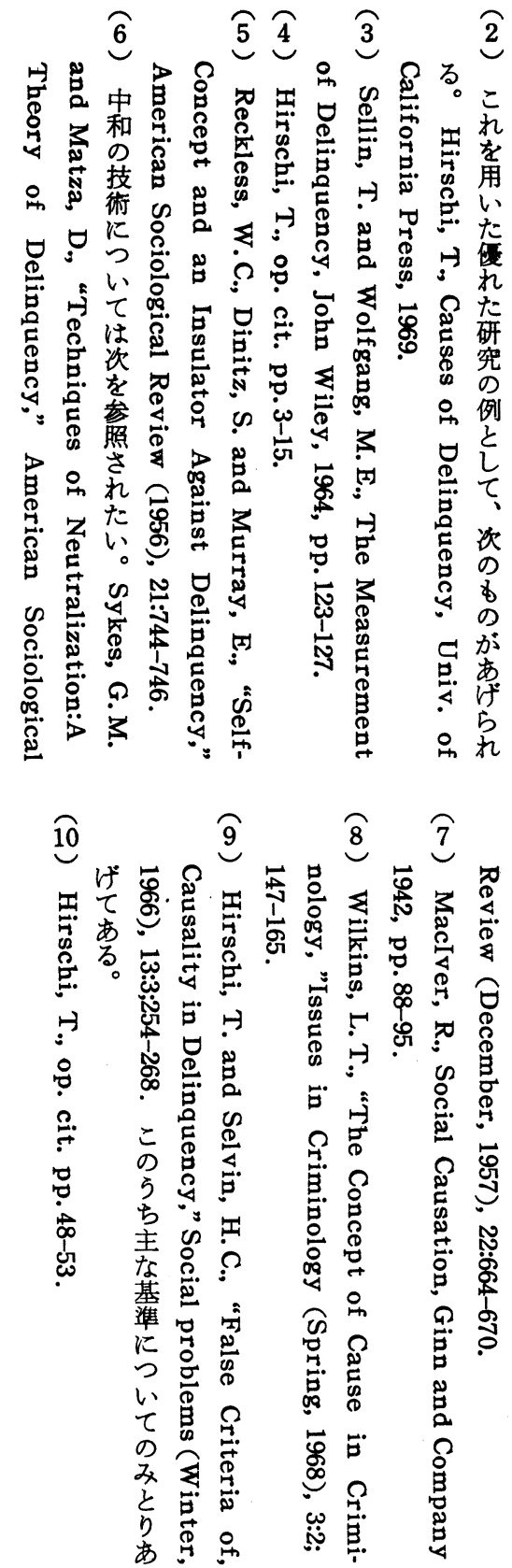
behaviors, the increasing number of junior high school graduates who have not been offered admission to senior high schools, and the "admission test industry".

\title{
A Note on Causal Analysis of Delinquency
}

\author{
Kanehiro Hoshino \\ (National Research Institute of Police Science)
}

1. Two principal approaches to the problem of definitions are usually recognized as the legal and the behavioral or sociological. There seems to be extensive agreement that delinquency consists of behaviors recognized as undesirable or behaviors formally prohibited by law. However, a number of questions always arise as to this seemingly simple way of defining term. One of such questions is concerned with the problem of what is involved in the idea of delinquency. Is it a single act or must there be a series of related acts, a pattern of behavior in order to establish the fact of delinquency? There are also questions about who is a delinquent and when one becomes a delinquent. Whether causal analysis of delinquency is possible depends on how these basic questions are answered.

2. Three fundamental perspectives on delinquency dominate the current scene. They are strain or motivational theories, control or bond theories and cultural deviance theories. Although most current theories of delinquency contain at least two and occasionally all three of these perspectives, reconciliation of assumptions is very difficult. Each investigator should begin framing his perspective in order to analyze causes of delinquency.

3. There are three principal requirements that an empirical investigator must meet in order to be able to say that A causes B:

1) $A$ and $B$ are statistically associated.

2) $A$ is causally prior to $B$.

3) The association between $A$ and $B$ does not disappear when the effects of other variables causally prior to both $\mathrm{A}$ and $\mathrm{B}$ are removed.

4. There have been many arguments among proponents of "general theory" or "multiple factor" approaches. Multiple factor adherents should state more explicitly the reasons for their choice of particular items for analysis and the general theorists 
should examine and make more extensive use of data. The causes of delinquency must be discussed more in probabilistic terms than in deterministic models.

\title{
Path Analysis applied to the Educational Selection Process - Factors in the Admission to High Schools -
}

\author{
Morikazu Ushiogi \\ (Nagoya University)
}

In this paper path analysis is applied to the selection process to high schools. In the causal model here used the variable to be explained is the admission or nonadmission to high schools and the explaining variables are educational levels, occupational status, and income levels of parents and educational attainments of children. Equation system is as follows:

$$
\begin{aligned}
& X 2=0.395 \times 1\left(R^{2}=0.152\right) \\
& X 3=0.142 \times 2+0.210 \times 1\left(R^{2}=0.088\right) \\
& X 4=0.377 \times 3+0.067 \times 2+0.149 \times 1\left(R^{2}=0.218\right) \\
& X 5=0.491 \times 4+0.261 \times 3+0.019 \times 2+0.110 \times 1\left(R^{2}=0.485\right)
\end{aligned}
$$

(X1 means the educational levels of parents, X2 means occupational status of parents, X3 means income levels of family, X4 means educational attainments of children, and X5 means the admission or non-admission to high schools)

Results of path analysis shows that the most influential variable in the direct effect on admission is educational attainment (path coefficient X4 $\rightarrow$ X5 equals 0.491 ) and occupational status and educational level of parents are less influential both in their direct and indirect effects. On the contrary, income level of family, in spite of less direct effect on admission (path coefficient 0.261 ), has a fairly high effect on the educational attainment of child (path coefficient X3 $\rightarrow \mathrm{X} 4$ is 0.377 ) and determines through it the chance of admission to high school in a fairly high degree. The effect of income level on admission through educational attainment of child amounts to 0.446. It means that income determines the admission in the nearly same degree as the the educational attainment of child. Even in the stage of high admission (about $90 \%$ of graduates from middle schools enter high schools) family background plays unneglectable role in the educational selection process. 